\title{
VIBGYOR: A SUSTAINABILITY ASSESSMENT TOOL FOR RESIDENTIAL BUILDING
}

\author{
Linu T.Kuriakose ${ }^{1}$, L. Krishnaraj ${ }^{2}$, P.T.Ravichandran ${ }^{3}$, R.Annadurai $^{4}$ \\ ${ }^{1}$ Post Graduate Student, Civil Engineering Department, SRM University, Chennai, Tamil Nadu, India \\ ${ }^{2}$ Assistant Professor, Civil Engineering Department, SRM University, Chennai, Tamil Nadu, India \\ ${ }^{3}$ Professor, Civil Engineering Department, SRM University, Chennai, Tamil Nadu, India \\ ${ }^{4}$ Professor and Head, Civil Engineering Department, SRM University, Chennai, Tamil Nadu, India
}

\begin{abstract}
Sustainable development is forward looking and also a continuous mission for the development of human society. This paper intends to identify the key indicators of sustainability for residential projects by maintaining a proper balance between the environmental, economic, social and cultural aspects in the design, construction and use of the buildings. A survey has been conducted to identify the principal indicators leading to the success of sustainability principles. Based on extensive literature work, 73 indicators concerning sustainability were summarized. Software Package for Social Science and relative importance index technique was used to find the ranking of the variables. This paper also aims at simulating a tool for the sustainability assessment of residential buildings which can be used by the architects, designers, planners and local bodies as well as it acts as a auditing tool.
\end{abstract}

Keywords: Sustainability, Indicators, Domains, Relative Importance Index, SPSS, Questionnaire Analysis

\section{INTRODUCTION}

The Indian construction industry is one of the fastest growing sectors and the current growth rate is more than $10 \%$. Reports say that India is one of the top spending nations of construction in the world. The report 'Global construction 2020', estimates that India will be the third largest global construction market after China. But the current construction management system in the country is suffering from an unplanned economic growth and excessive resource consumption that limits the building a more sustainable infrastructure which is essential for suitable human life [1]. So, now there is a need to highlight the need of sustainability in the present construction industry. The sustainable development movement has been evolving worldwide for almost two decades, and has caused significant changes in the construction industry.

Sustainability is the foundational principle underlying various efforts to ensure a decent quality of life for future generations, i.e. meeting the needs of the present without compromising the ability of the future generations to meet their needs [2]. A subset of sustainable development, sustainable construction, addresses the role of the built environment in contributing to the overarching vision of sustainability. The Counseil International du Batiment (CIB), an international construction research networking organization defines the goal of sustainable construction is to create and operate a healthy built environment based on resource efficiency and ecological design. The aim is to identify the key indicators of sustainability and to frame a sustainability assessment tool for residential buildings.

\section{SCOPE OF STUDY}

The paper aims to develop an effective methodology for assessing the sustainability of the buildings and to develop a strategic model for implementing sustainable aspects in construction. The purpose of the sustainability assessment tool is to gather and report information for decision making during different phases of the design, construction, operation and maintenance of the building. A variety of sustainable assessment tools presently available in the industry are widely used in environmental product declarations. The assessment tools either environmental or performance based, is under evolution because of their limitations. The main goal, at present is to develop and implement a methodology that helps in the designing phase itself. This methodology keeps a proper balance between all the dimensions of sustainability, namely environmental, economical and social aspects. The method will be easily adaptable to all types of building and here especially focusing on residential building.

According to Ness et.al [3], "the purpose of sustainability assessment is to provide decision makers with an evaluation of global to local integrated nature-society systems in short term and long term perspectives in order to assist them to determine which actions should or should not be taken in an attempt to make society sustainable". Ricardo Mateus and Luis Braganca have found out that the average performance level of a 
sustainable building is $10 \%$ higher than the conventional building practice [4].

In developing countries like India, the increasing population and increasing standards of living due to urbanization, has been a reason in increase of the construction activities [5]. The building along with the resources uses energy and raw materials which are scarce. Also they generate more amounts of solid waste and harmful atmospheric emissions. So the sustainable building and its assessment is aiming to achieve growth in the urban area. The assessment method helps the design engineers, planners, developers, architects, local bodies and the client to understand the principles of sustainable building and its design. The construction industry worldwide has already started adopting the sustainable construction.

\section{DESIGN AND RESEARCH METHODOLOGY}

The initial step was to choose the most appropriate criteria to formulate an indicator set which will consider the building's performance in relation to the dimensions of sustainability namely environmental, social, culture and economy. The appropriate indicators which forms the basis of framing the questionnaire surveys were selected by reviewing the literatures and the importance of the indicators was found by the survey with a number of professionals by inviting the key people from each of the following disciplines to participate namely architects, engineers and the builders group. A flow chart representing the methodology of tool formulation is shown in fig. 1.

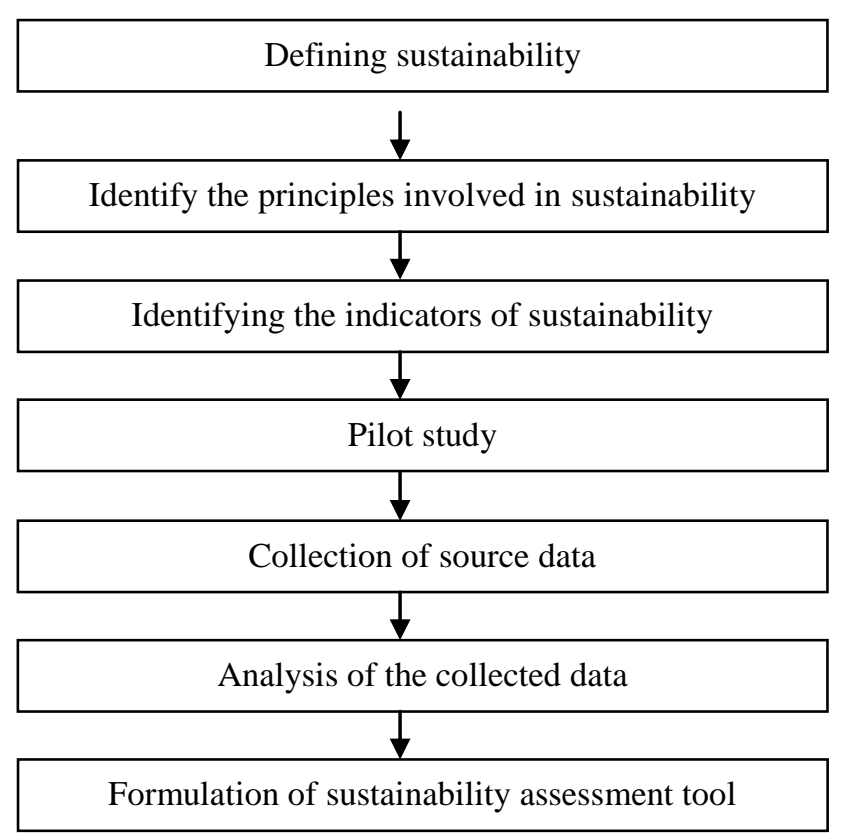

Fig -1: Methodology of the Tool Formulation

The questionnaire was framed which included about 73 indicators under 9 domains. The respondents were asked to indicate the basic data (which included their name, organization, designation, experience etc.) and rate the indicators as 'very important', 'important' and 'less important'. About 90 questionnaires were circulated in various regions of Kerala and Chennai. 51 responded back indicating a response rate of $57 \%$. The questionnaires were analysed using 'the Software Package for Social Sciences' (SPSS, version 20.0) developed by IBM.

\subsection{Development of Indicators}

The initial step of framing the sustainability assessment tool is to identify the key indicators of sustainability. Literatures were used to identify the indicators of sustainability. The building assessment methods used for the identification of indicators include BREEAM, LEED, CASBEE and Estidama. Table 1 highlights the features that distinguish each assessment tool. BREEAM and LEED are the most commonly used tools, internationally. Not all the tools consider all the dimensions of sustainability. Estidama is the only tool, among the study, which considers the economic and cultural aspects of sustainability.

Table -1: Comparison of Rating Tools Categories

\begin{tabular}{|l|l|l|l|l|}
\hline Items & $\begin{array}{l}\text { BREE } \\
\text { AM }\end{array}$ & $\begin{array}{l}\text { LEE } \\
\text { D }\end{array}$ & $\begin{array}{l}\text { ESTIDA } \\
\text { MA }\end{array}$ & $\begin{array}{l}\text { CASB } \\
\text { EE }\end{array}$ \\
\hline Energy & $\sqrt{ }$ & $\sqrt{ }$ & $\sqrt{ }$ & $\sqrt{ }$ \\
\hline Water & $\sqrt{ }$ & $\sqrt{ }$ & $\sqrt{ }$ & $\sqrt{ }$ \\
\hline Waste & $\sqrt{ }$ & $\sqrt{ }$ & $\sqrt{ }$ & $\sqrt{ }$ \\
\hline Materials & $\sqrt{ }$ & $\sqrt{ }$ & $\sqrt{ }$ & $\sqrt{ }$ \\
\hline $\begin{array}{l}\text { Indoor } \\
\text { environment } \\
\text { quality }\end{array}$ & $\sqrt{ }$ & $\sqrt{ }$ & $\sqrt{ }$ & $\sqrt{ }$ \\
\hline Economics & & & $\sqrt{ }$ & \\
\hline Management & $\sqrt{ }$ & & $\sqrt{ }$ & $\sqrt{ }$ \\
\hline $\begin{array}{l}\text { Mobility and } \\
\text { transportation }\end{array}$ & $\sqrt{ }$ & $\sqrt{ }$ & $\sqrt{ }$ & \\
\hline $\begin{array}{l}\text { Emission and } \\
\text { pollution }\end{array}$ & $\sqrt{ }$ & $\sqrt{ }$ & $\sqrt{ }$ & $\sqrt{ }$ \\
\hline $\begin{array}{l}\text { Land use, site } \\
\text { and ecology }\end{array}$ & $\sqrt{ }$ & $\sqrt{ }$ & $\sqrt{ }$ & \\
\hline Resources and & & $\sqrt{ }$ & & $\sqrt{ }$ \\
\hline $\begin{array}{l}\text { Cultural and } \\
\text { social }\end{array}$ & & & $\sqrt{ }$ \\
\hline
\end{tabular}

The indicators chosen for this particular study cover all the dimensions of sustainability. For this tool, there are mainly nine domains of sustainability indicators selected and are shown in table 2 . Initially about 80 indicators were selected and through iterations it was reduced to 73 . Iterations were done by the pilot study in order to check the practicability of the set of indicators. 
Table -2: Domains of Sustainability Indicators

\begin{tabular}{|l|l|}
\hline Code & Domains \\
\hline A & Sustainable Site \\
\hline B & Economic Aspects \\
\hline C & Water Efficiency \\
\hline D & Energy Efficiency \\
\hline E & Material and Resources \\
\hline F & Indoor Environmental Quality \\
\hline G & Environment Loading \\
\hline H & Social and Cultural Aspects \\
\hline I & Service Quality \\
\hline
\end{tabular}

There are sub-domains for sustainable site and indoor environmental quality. Sustainable site has got three subdomains namely site selection, project planning, urban development; indoor environmental quality has got air quality, ventilation, thermal comfort and acoustics as the sub-domains. Questionnaires was preferred as the best effective tool for data collection as it gives each individual as well as company's opinion regarding each indicator of sustainability. The relevant data was collected by a structured, close-ended questionnaire survey.

\subsection{Method of Analysis}

The software package for social science was used to analyze the information obtained from the questionnaire survey. A 3point Likert scale was used in which 3 represents 'very important', 2 for 'important' and 1 for 'less important'. The numbers assigned neither indicate that the intervals between scales are not equal nor they indicate absolute quantities. The indicators were measured on ordinal scale as they can be ordered or ranked according to their mean. An ordinal scale is a ranking or rating of data that normally uses integers in ascending or descending order. The reliability analysis was done to check the internal consistency of the responses among the 51 questionnaires and the reliability of the Likert scale. The Cronbach's alpha is used to measure the reliability of the questionnaire between each field and the mean of the whole fields of the questionnaire. The normal range of Cronbach's alpha value is between 0.0 and +1.0 and a higher value reflects a higher degree of internal consistency. The Cronbach's alpha $(\alpha)$ was obtained as 0.947 indicating that the questionnaire is excellent $(\alpha>0.9$ excellent) and the three-point scale was reliable for the study.[6]

When the statistical data is described in numerical measures it is called descriptive statistics. The descriptive statistics is obtained from the SPSS which include the measures of central tendency and measures of dispersion. The most common and useful measure of central tendency is arithmetic mean. The mean scores for the data obtained were used to find the rank of the indicators. Similarly the relative importance index (RII) for each indicator was found out using equation 1 .

$$
\mathrm{RII}=\frac{\Sigma \mathrm{W}}{\mathrm{A} \times \mathrm{N}} \times 100
$$

Where ' $\mathrm{W}$ ', is the weighting or the scale given by the respondent on the Likert scale. A is the highest weight (3, in this case) and $\mathrm{N}$ is the total number of sample (51, in this case).The relative importance index percentage was also used to rank the indicators. The relative importance of the indicator set was found out and based on the results obtained the tool was framed.

\section{RESULTS AND DISCUSSION}

Among the responders, 7 were architects, 13 were builders and 31 were identified as engineers. The engineer category includes project managers, estimation engineer and planning engineer. $39 \%$ of the responders were having an experience more than 10 years and $25 \%$ of the responders have an experience below 5 years. The mean of the indicators was obtained in the descriptive statistics. The ranking by domain and the overall ranking was done. Similarly the RII for each factor was determined and were ranked accordingly. The results for each domain are shown separately in table 3 .

Based on the samples, when the mean rankings of the indicators comprising each domain are added up and divided by the no. of indicators, the average ranking of the domain was obtained, indicating the relative importance. The results show that the indicator 'water quality' has got the highest mean value 2.39 suggesting that this was the most important indicator from the indicator set and has got the rank one. Water quality comes under the sub-domain project planning. Indian construction industry is a water intensive industry. Water quality is followed by effective ventilation in naturally and mechanically ventilated areas. Increasing the ventilation rate can improve the indoor environmental quality. It is followed by Retention of rain water, optimum energy performance and green spaces and trees for shading with rank five. Rain water harvesting is the activity of direct collection of rain water. The main aim of the indicator, optimum energy performance, is to optimize the use of energy systems in buildings that maintain a specified indoor climate conductive to the functional requirements of the building. Trees and green spaces are very important because of the increasing pollution and carbon footprint. The least priority indicator was found to performance indicators with a mean value of 1.31 suggesting that most of the respondents have marked a lesser scale for the indicator. 
Table -3: Ranks of the Indicators

\begin{tabular}{|c|c|c|c|c|c|c|}
\hline Domain & Sub-domain & Indicator & Mean & $\begin{array}{c}\text { Rank by } \\
\text { domain }\end{array}$ & $\begin{array}{l}\text { Overall } \\
\text { ranking }\end{array}$ & $\begin{array}{c}\text { RII } \\
\text { ranking }\end{array}$ \\
\hline \multirow{22}{*}{$\begin{array}{l}\text { A. Sustainable } \\
\text { Site }\end{array}$} & \multirow{9}{*}{$\begin{array}{l}\text { A1. Site } \\
\text { Selection }\end{array}$} & A1a. Ecological value & 1.78 & 5 & 54 & 54 \\
\hline & & A1b. Agricultural value & 1.61 & 8 & 67 & 67 \\
\hline & & A1c. Flooding possibility & 2.2 & 1 & 8 & 8 \\
\hline & & A1d. Potential to contaminate nearby bodies of water. & 1.9 & 3 & 34 & 34 \\
\hline & & A1e. Brownfield development & 1.69 & 6 & 61 & 61 \\
\hline & & A1f. Proximity to public transport & 1.98 & 2 & 21 & 21 \\
\hline & & A1g. Near to residential area & 1.82 & 4 & 44 & 44 \\
\hline & & A1h. Near to recreation area & 1.59 & 9 & 69 & 69 \\
\hline & & A1i. Near to commercial area & 1.67 & 7 & 63 & 63 \\
\hline & \multirow{6}{*}{$\begin{array}{l}\text { A2. Project } \\
\text { Planning }\end{array}$} & A2a. Environmental impact of development & 1.9 & 6 & 35 & 35 \\
\hline & & A2b. Conserve existing natural area & 1.9 & 5 & 33 & 33 \\
\hline & & A2c. Surface water management system & 1.94 & 4 & 25 & 25 \\
\hline & & A2d. Water quality & 2.39 & 1 & 1 & 1 \\
\hline & & A2e. Potable water system & 2.18 & 2 & 11 & 11 \\
\hline & & A2f. Site orientation & 1.98 & 3 & 20 & 20 \\
\hline & \multirow{7}{*}{$\begin{array}{l}\text { A3. Urban } \\
\text { Development }\end{array}$} & A3a. Development density & 1.88 & 4 & 36 & 36 \\
\hline & & A3b. Provision of public open spaces & 1.96 & 3 & 24 & 24 \\
\hline & & A3c. Encouragement of walking & 1.71 & 6 & 59 & 59 \\
\hline & & A3d. support for bicycle use & 1.51 & 7 & 72 & 72 \\
\hline & & A3e. Alternate transportation & 1.78 & 5 & 53 & 53 \\
\hline & & A3f. Green space and trees for shading & 2.24 & 1 & 5 & 5 \\
\hline & & A3g. Parking facility & 2.14 & 2 & 15 & 15 \\
\hline \multirow{5}{*}{$\begin{array}{l}\text { B. Economic } \\
\text { Aspects }\end{array}$} & & B1a. Initial cost & 1.82 & 4 & 43 & 43 \\
\hline & & B1b. Minimize life-cycle cost & 2.06 & 2 & 17 & 17 \\
\hline & & B1c. Minimize construction cost & 1.98 & 3 & 19 & 19 \\
\hline & & B1d. Minimize operation and maintenance cost & 2.22 & 1 & 6 & 6 \\
\hline & & B1e. Renovation and destruction cost & 1.8 & 5 & 48 & 48 \\
\hline \multirow{3}{*}{$\begin{array}{l}\text { C. Water } \\
\text { Efficiency }\end{array}$} & & $\begin{array}{l}\text { C1a. Effective water use in construction and building } \\
\text { activities }\end{array}$ & 2.2 & 1 & 9 & 9 \\
\hline & & C1b. Reduced waste water generation & 2.1 & 2 & 16 & 16 \\
\hline & & C1c. Water efficiency in air conditioning system & 1.96 & 3 & 23 & 23 \\
\hline \multirow{2}{*}{$\begin{array}{l}\text { D. Energy } \\
\text { Efficiency }\end{array}$} & & D1a. Optimum energy performance & 2.25 & 1 & 4 & 4 \\
\hline & & D1b. Use of renewable energy & 2.14 & 2 & 14 & 14 \\
\hline \multirow{8}{*}{$\begin{array}{l}\text { E. Material } \\
\text { and Resources }\end{array}$} & & E1a. Reuse of existing structure & 1.76 & 7 & 56 & 56 \\
\hline & & E1b. Avoidance of toxic substances & 1.92 & 2 & 28 & 28 \\
\hline & & E1c. Use of recycled material & 1.8 & 5 & 47 & 47 \\
\hline & & E1d. Cement supplementing material use in concrete & 1.76 & 6 & 55 & 55 \\
\hline & & E1e. Minimize finishing material & 1.65 & 8 & 64 & 64 \\
\hline & & E1f. Use of local and renewable material & 1.92 & 1 & 27 & 27 \\
\hline & & E1g. Use of environmentally compatible material & 1.88 & 3 & 38 & 38 \\
\hline & & E1h. Use of certified wood & 1.82 & 4 & 45 & 45 \\
\hline \multirow{4}{*}{$\begin{array}{l}\text { F. Indoor } \\
\text { Environmental } \\
\text { Quality }\end{array}$} & \multirow{3}{*}{ F1. Air Quality } & F1a. Construction indoor air quality management plan & 2.18 & 1 & 12 & 12 \\
\hline & & F1b. Minimum exposure to chemical pollutants & 1.88 & 2 & 37 & 37 \\
\hline & & F1c. Low-emitting interior finishing material & 1.78 & 3 & 52 & 52 \\
\hline & F2.Ventilation & $\begin{array}{l}\text { F2a. Effective ventilation in naturally and } \\
\text { mechanically ventilated spaces }\end{array}$ & 2.27 & 1 & 2 & 2 \\
\hline
\end{tabular}


Table -3: Ranks of the Indicators (continued)

\begin{tabular}{|c|c|c|c|c|c|c|}
\hline Domain & Sub-domain & Indicator & Mean & $\begin{array}{l}\text { Rank by } \\
\text { domain }\end{array}$ & $\begin{array}{l}\text { Overall } \\
\text { ranking }\end{array}$ & $\begin{array}{c}\text { RII } \\
\text { ranking }\end{array}$ \\
\hline & \multirow{2}{*}{$\begin{array}{l}\text { F3. Thermal } \\
\text { comfort and } \\
\text { humidity }\end{array}$} & $\begin{array}{l}\text { F3a. Temperature in naturally and } \\
\text { mechanically ventilated spaces }\end{array}$ & 2.18 & 1 & 10 & 10 \\
\hline & & F3b. Humidity control & 1.92 & 2 & 31 & 31 \\
\hline & \multirow[t]{5}{*}{ F4. Acoustics } & F4a. Illumination-light quality & 2.2 & 1 & 7 & 7 \\
\hline & & F4b. Lighting system degree of control & 1.84 & 4 & 41 & 41 \\
\hline & & F4c. Noise acoustics & 1.92 & 3 & 30 & 30 \\
\hline & & F4d. Exterior noise & 1.92 & 2 & 29 & 29 \\
\hline & & F4e. Efficiency of HVAC system & 1.69 & 5 & 60 & 60 \\
\hline \multirow{7}{*}{$\begin{array}{l}\text { G. } \\
\text { Environmental } \\
\text { loading }\end{array}$} & & $\begin{array}{l}\text { G1a. Greenhouse gas emissions during } \\
\text { construction and building operations }\end{array}$ & 1.9 & 4 & 32 & 32 \\
\hline & & $\begin{array}{l}\text { G1b. Annual greenhouse gas emissions from } \\
\text { facility operations }\end{array}$ & 1.84 & 6 & 40 & 40 \\
\hline & & $\begin{array}{l}\text { G1c. Solid waste from construction and } \\
\text { building operations }\end{array}$ & 2.16 & 2 & 13 & 13 \\
\hline & & G1d. Retention of rain water & 2.27 & 1 & 3 & 3 \\
\hline & & G1e. Construction impact to soil erosion & 1.98 & 3 & 18 & 18 \\
\hline & & $\begin{array}{l}\text { G1f. Impact on access to daylight to } \\
\text { adjoining property }\end{array}$ & 1.86 & 5 & 39 & 39 \\
\hline & & G1g. Heat island effect & 1.73 & 7 & 58 & 58 \\
\hline \multirow{7}{*}{$\begin{array}{l}\text { H. Social and } \\
\text { cultural } \\
\text { aspects }\end{array}$} & & H1a. Minimize construction accidents & 1.82 & 2 & 42 & 42 \\
\hline & & H1b. Access to handicapped persons & 1.82 & 3 & 46 & 46 \\
\hline & & $\begin{array}{l}\text { H1c. Social utility of primary building } \\
\text { function }\end{array}$ & 1.8 & 4 & 49 & 49 \\
\hline & & H1d. Sanitation to construction workers & 1.94 & 1 & 26 & 26 \\
\hline & & H1e. Provision of employment opportunities & 1.51 & 5 & 51 & 51 \\
\hline & & H1f. Cultural value of existing building & 1.78 & 6 & 65 & 65 \\
\hline & & H1g. Maintain heritage value & 1.63 & 7 & 71 & 71 \\
\hline \multirow{8}{*}{$\begin{array}{l}\text { I. Service } \\
\text { quality }\end{array}$} & & I1a. Safety and security & 1.78 & 2 & 50 & 50 \\
\hline & & I1b. Spatial efficiency & 1.55 & 7 & 70 & 70 \\
\hline & & $\begin{array}{l}\text { I1c. Limitation of future risk, exposure and } \\
\text { liability }\end{array}$ & 1.61 & 6 & 68 & 68 \\
\hline & & I1d. Service life planning and costing & 1.69 & 4 & 62 & 62 \\
\hline & & $\begin{array}{l}\text { I1e. Ability to modify building management } \\
\text { system }\end{array}$ & 1.63 & 5 & 66 & 66 \\
\hline & & I1f. Adaptability to future changes & 1.96 & 1 & 22 & 22 \\
\hline & & I1g. Performance incentives & 1.31 & 8 & 73 & 73 \\
\hline & & I1h. Skilled operation staff & 1.73 & 3 & 57 & 57 \\
\hline
\end{tabular}

The results of relative importance index suggest that the ranking was same as that of the mean ranking. The figure 2 shows the mean ranking of the domains of sustainability. On the account of its impacts on the environment as well as its vitality for construction sector; energy efficiency was the domain which is considered to be the most significant domain followed by water efficiency, indoor environmental quality, environmental loading, economic aspects, sustainable site, material and resources, social and cultural aspects. Water preservation as well as efficiency is one of the most important elements in human life and construction sector consumes about $15 \%$ of the overall fresh water resources.
The quality of indoor environment is considered as an important domain due to its overlapping features with other domains. It aims at providing a healthy and comfortable indoor place with respect of visual comfort, sound comfort and thermal comfort. The prime goal of the domain environmental loading is to protect the surrounding environment form the negative impacts of the building . in addition it provides healthy and comfortable environment for the building users. The domain service quality obtained the lesser mean ranking. The results suggest that in residential building these domains should be given the priorities in order. 


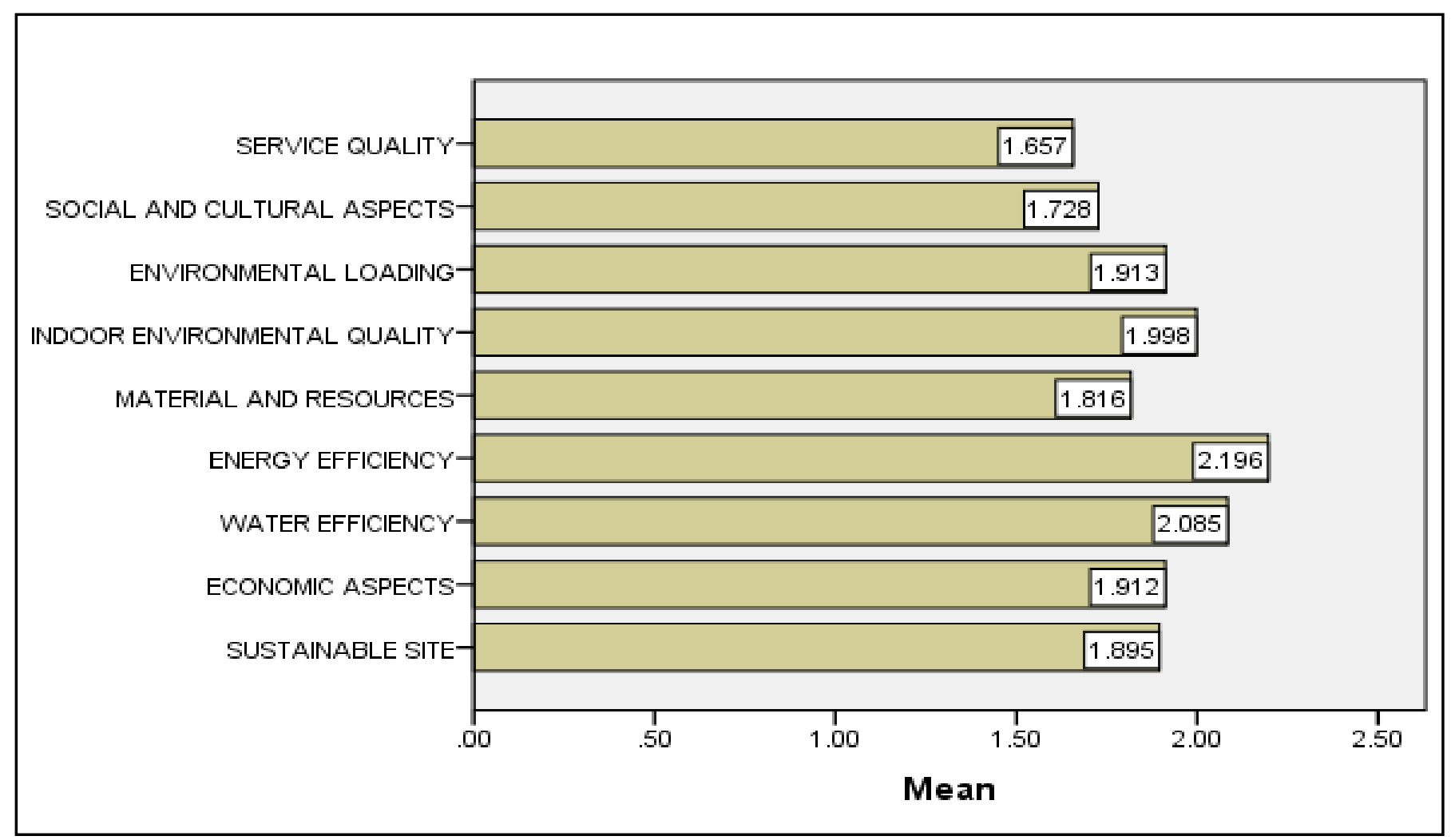

Fig -2: Mean Rankings of the Domains

\section{FRAMING OF SUSTAINABILITY ASSESSMENT TOOL}

The sustainability assessment tool is an evaluation tool that measures the performance of the building through its life cycle. Based on the mean values obtained from the SPSS, the levels of indicators were fixed. Three levels of indicators were made depending on the ranks. Level one consists of indicators having a mean in the range of 2.00-3.00 because these are the indicators for which the most of the respondents have given a scale of 3 (very important). Level two consists of the indicators with a mean value ranging from 1.80- 1.99. The level three consists of indicators having a mean less than 1.80. According to Lee et.al. [7] weighting is the heart of all assessment schemes since it will dominate the overall performance score of the building being assessed. A three point credit system was awarded to the indicators based on the levels. A level one indicator was awarded with 3 credits, level two with 2 credits and level three gets 1 credit. The credits are awarded only if the criteria lay down by the tool is satisfied by the building. The criteria were fixed with reference to the following manual namely, GRIHA Manual, IGBC rating systems and LEED. These criteria were framed in such a way that it complies with the rules and regulations of the Indian Government and also the practicability of these criteria were considered. Table 4 represents the credits awarded to the indicators. The code of the indicator is given. The total credits accounts to 133 and for each innovation in any domain one extra credit awarded.

The new tool is given the name 'VIBGYOR'; each colour indicates the badge given to the buildings. If, the building under assessment satisfies all the criteria, then it is awarded with a 'VIOLET' badge indicating that the building is highly sustainable. As the credits obtained reduce, the colour badge obtained is changed. The minimum and maximum credit to each colour badge is given in table 5 . For a building to be said as sustainable and to get a sanction, at least it should get a colour badge from 'GREEN'. GREEN indicates the neutral level of the colour badge system. A system which has got a RED badge signifies that it has given least importance for sustainability and the principles of sustainability are not adopted or the least adopted. Unlike the other assessment tools available in the present construction market, this tool considers all the dimensions of sustainability equally and a proper criterion is laid down for all the indicators. The assessment tool VIBGYOR provides a methodological framework to evaluate the sustainability in a building throughout its entire life-cycle design, construction and operation. 
Table -4: Credits Assigned to the Indicators

\begin{tabular}{|c|c|c|c|c|c|}
\hline Code & Level & Credits & Code & Level & Credits \\
\hline A1a & Level 3 & 1 & E1f & Level 2 & 2 \\
\hline A1b & Level 3 & 1 & E1g & Level 2 & 2 \\
\hline A1c & Level 1 & 3 & E1h & Level 2 & 2 \\
\hline A1d & Level 2 & 2 & F1a & Level 1 & 3 \\
\hline A1e & Level 1 & 1 & F1b & Level 2 & 2 \\
\hline A1f & Level 2 & 2 & F1c & Level 3 & 1 \\
\hline A1g & Level 2 & 2 & F2a & Level 1 & 3 \\
\hline A1h & Level 3 & 1 & F3a & Level 1 & 3 \\
\hline A1i & Level 3 & 1 & F3b & Level 1 & 3 \\
\hline A2a & \multirow[b]{2}{*}{ Level 2} & \multirow[b]{2}{*}{2} & F4a & Level 1 & 3 \\
\hline A2b & & & F4b & Level 1 & 3 \\
\hline A2c & Level 2 & 2 & F4c & Level 2 & 2 \\
\hline A2d & \multirow[b]{2}{*}{ Level 1} & \multirow[b]{2}{*}{3} & F4d & Level 2 & 2 \\
\hline A2e & & & F4e & Level 3 & 1 \\
\hline A2f & Level 2 & 2 & G1a & \multirow[b]{2}{*}{ Level 2} & \multirow[b]{2}{*}{2} \\
\hline A3a & Level 2 & 2 & G1b & & \\
\hline A3b & Level 2 & 2 & G1c & Level 1 & 3 \\
\hline A3c & Level 3 & 1 & G1d & Level 1 & 3 \\
\hline A3d & Level 3 & 1 & G1e & Level 2 & 2 \\
\hline A3e & Level 3 & 1 & G1f & Level 2 & 2 \\
\hline A3f & Level 1 & 3 & G1g & Level 3 & 1 \\
\hline A3g & Level 1 & 3 & H1a & Level 3 & 1 \\
\hline B1a & Level 2 & 2 & H1b & Level 3 & 2 \\
\hline B1b & Level 1 & 3 & H1c & Level 3 & 2 \\
\hline B1c & Level 1 & 3 & H1d & Level 3 & 2 \\
\hline B1d & Level 2 & 2 & H1e & Level 3 & 1 \\
\hline B1e & Level 2 & 2 & H1f & & \\
\hline C1a & Level 1 & 3 & H1g & Level 3 & 1 \\
\hline C1b & Level 1 & 3 & I1a & Level 3 & 1 \\
\hline C1c & Level 2 & 2 & I1b & Level 3 & 1 \\
\hline D1a & Level 1 & 3 & I1c & Level 3 & 1 \\
\hline D1b & Level 1 & 3 & I1d & Level 3 & 1 \\
\hline E1a & Level 2 & 2 & 11e & Level 3 & 1 \\
\hline E1b & Level 2 & 2 & I1f & Level 3 & 2 \\
\hline E1c & Level 2 & 2 & I1g & Level 3 & 1 \\
\hline E1d & Level 3 & 1 & I1h & Level 3 & 1 \\
\hline E1e & Level 3 & 1 & & & \\
\hline
\end{tabular}

Applicability of the tool: The sustainability assessment tool discussed here can be used to assess the sustainability of residential buildings. This constitutes both single and multidwelling units, which includes, single homes, apartments, villas, and bungalow. The local bodies can make use of this tool as checking tool before giving sanctions to the construction of these kinds of buildings. Especially in India, the numbers of multi-dwelling units are increasing as there is an increase in the population of the country resulting in urbanization. The tool will help in perceiving the acceptability of the stakeholders including government, clients, architects, engineering consultants, contractors and suppliers. They can refer as a guide and can help the country to increase the sustainability in construction.
Table -5: Marks Allotted to Each Badge

\begin{tabular}{|c|c|c|}
\hline \multirow{2}{*}{ Badge code } & Badge & Range of marks \\
\hline V & Violet & $120-133$ \\
\hline I & Indigo & $106-119$ \\
\hline B & Blue & $93-105$ \\
\hline G & Green & $80-92$ \\
\hline Y & Yellow & $67-79$ \\
\hline O & Orange & $53-66$ \\
\hline R & Red & $<52$ \\
\hline
\end{tabular}

\section{CONCLUSIONS}

In this paper, the current status of sustainability in the country was studied with the help of the indicators of sustainability. The results from the analysis indicate that individual indicators were given different levels of significance in practice. Among the indicators considered in the building sector, water quality was found to be the most important. The domain which is given the highest priority is energy efficiency. Use of the sustainability assessment tool will greatly simplify the measurement of sustainable development. Even though there are different tools available in the market to assess the building in terms of sustainability, this tool stands for its simplicity. The tool provides a methodological framework to measure and monitor the performance of the building. It can be used as an auditing tool by the local government authorities and as a verification tool too. This tool, similar to the LEED and GRIHA is additive in nature, but the credits awarded were different and aims to develop a common approach to modelling all criteria appropriately for carrying out sustainability. The current research study was limited to the residential buildings and multi-dwelling units in India. In recommendation, the implementation of this new tool requests for the participation of all the stakeholders involved in construction.

\section{REFERENCES}

[1] Lauren Bradely Robichaud, Vittal S.Anantatmula, "Greening project management practices for sustainable construction", Journal of Management in Engineering, ASCE, vol. 27 pp. 48-57, 2011

[2] Rajesh Kumar Singh, H.R. Murty, S.K. Gupta, A.K. Dikshit, "An overview of sustainability assessment methodologies", Ecological Indicators , vol. 9 pp. 189212, 2007

[3] Ness B, Urbel Piirsalu. E, Anderberg.S, Olsson L., "Categorising tools FOS sustainability assessment", Ecological Economics, vol. 60, pp.498-508, 2007

[4] Ricardo Mateus, Luis Braganca, “ Sustainability assessment and rating of buildings: developing the methodology SB tool-H", Building and Environment, vol. 46, pp.1962-1971, 2011 
[5] Rajiv Bhatt and J. E. M. Macwan, "Global Weights of Parameters for Sustainable Buildings from Consultants' Perspectives in Indian Context", Journal of Architecture Engineering, vol. 18, pp.233-141, 2012

[6] Darren George and Paul Mallery ,SPSS for Windows17.0 update, Tenth edition

[7] Lee, W.L., Chau C.K. Yik F.W.H, Burnett J. Tse M.S, "The study of the credit-weighting scale in a building environmental assessment scheme", Building and Environment, vol. 37, pp. 1385-1396, 2002

[8] Antonio Boggia, Carla Cortina, “ Measuring sustainable development using a multi-criteria model: a case study ", Journal of Environmental Management vol. 91, pp.2301-2306, 2010

[9] Appu Happio, Pretti Viitaniemi, "A critical review of building environmental assessment tools", Environmental Impact Assessment Review vol. 28, pp. 469-482, 2008

[10] Ayyoob Sharifi, Akito Murayama, "A critical review of seven neighbourhood sustainability assessment tools", Environmental Impact Assessment Review vol. 38, pp. 73-87, 2013

[11] Benjamin Herazo, Gonzalo Lizarralde and Raymond Pacquin " Sustainable development in the building sector: a Canadian case study on the alignment of strategic and tactical management", Project Management Journal vol. 43, pp.84-100, 2012

[12] Beijia Huang, Haizhen Yang, Volker Mauerhofer, Ru Guo, "Sustainability assessment of low carbon technologies-case study of the building sector in China", Journal of Cleaner Production vol. 32, pp. 244250, 2012

[13] C.P. Yip Robin, C.S. Poon, "Cultural shift towards sustainability in the construction industry of Hong Kong", Journal of Environmental management vol. 90, pp. 3616-3628, 2009

[14] Grace K.C. Ding, "Sustainable construction-The role of environmental assessment tools", Journal of Environment Management vol. 86, pp.451-464, 2008

[15] H.Alwaer, D.J.Clements, " Key performance indicators and priority setting in using the multi-attribute approach for assessing sustainable intelligent buildings", Building and Environment vol. 45, pp.799807,2010

[16] J.T. San-Jose', R. Losadab, J. Cuadradob, I. Garruchoa, "Approach to the quantification of the sustainable value in industrial buildings", Building and Environment vol. 42, pp. 3916-3923, 2007

[17] Li-yin Shen, Vivian W.Y.Tam, Leona Tam, Ying-bo Ji, "Project feasibility study: the key to successful implementation of sustainable and socially responsible construction management practice", Journal of Cleaner Production vol. 18, pp.254-259, 2010

[18] Liyin Shen, Yuzhe Wu, Xiaoling Zhang , "Key assessment indicators for the sustainability of infrastructure projects ", Journal of Construction
Engineering and Management ,ASCE, pp.441-451, 2011

[19] N.W.Alnaser, R.Flanagan, W.E. Alnaser, "Model for calculating the sustainable building index in the kingdom of Bahrain ", Energy and Buildings, vol. 40, pp.2037-2043, 2008

[20] O.O. Ugwua, T.C. Haupt, "Key performance indicators and assessment methods for infrastructure sustainability - a South African construction industry perspective", Building and Environment, vol. 45, pp. 799-807, 2010

[21] Peter O.Akardiri, Paul O.Olomolaiye, Ezekiel A.Chinyio, "Multi-criteria evaluation model for the selection of sustainable materials for building projects", Automation in Construction, vol. 30, pp.113-125, 2013

[22] Riduan Yunus, Jay Yang, " Sustainability criteria for industrialised building systems in Malaysia", Procedia Engineering vol. 14, pp. 1590-1598, 2011

[23] Rodoolfo Valdes-Vasquez, Leidy E.Klotz, “ Social sustainability considerations during planning and design: Framework of processes for construction projects", Journal of Construction Engineering and Management, ASCE, vol. 139, pp.80-89, 2013

[24] Saleh H.Alyami, Yacine Rezgui, " Sustainable building assessment tool development approach", Sustainable Cities and Society, vol. 5, pp.52-62, 2012

[25] Salman Azhar, Wade A.Carlton, et.al., "Building information modelling for sustainable design and LEED rating analysis", Automation in Construction, vol. 20, pp.217-224, 2011

[26] Saulius Raslanas, Andrius Stasiukynas, Edita Jurgelaityte, "Sustainability assessment studies of recreational buildings", Procedia Engineering, vol. 57, pp.929-937, 2013

[27] S.R.Chandratilake, W.P.S Dias, “ Sustainability rating systems for buildings: comparisons and correlations ", Energy, pp.1-7, 2013

[28] Stefan Schaltegger, Maria Csutora, "Carbon accounting for sustainability and management, Status quo and challenges", Journal of cleaner production vol. 36, pp. $1-6,2012$

[29] Yao Hong, Shen Liyin, Tan Yongtao, Hao Jianli, “ Simulating the impacts of policy scenarios on the sustainability performance of infrastructure projects", Automation in Construction, vol. 20, pp.1060-1069, 2011

[30] Ying Chen, Gul E.Okudan, David R.Riley, “ Sustainable performance criteria for construction method selection in concrete buildings", Automation in Construction, vol. 19, pp.235-244, 2013 